\title{
War Injuries in Civilians Treated in Požega Hospital, Croatia
}

\author{
A Rukavina \\ $\mathrm{MD}, \mathrm{PhD}$.
}

Department of Surgery, Požega County Hospital, Požega, Croatia.

SUMMARY: The management of 131 civilians with war injuries, treated at the Department of Surgery, Požeg County Hospital, during the 1991-1995 period is presented. The majority of $55(42 \%)$ of patients were injured at the front line. There were $75(57.3 \%)$ of patients with explosive injuries $67(51.2 \%)$ involved the extremities, while 29 $(22.1 \%)$ involved the head. Seven $(5.3 \%)$ patients died. Amputation of part of an extremity was required in fivg $(3.8 \%)$ patients.

\section{Introduction}

The 1991-5 war in Croatia was characterized by artillery attacks on residential areas (1-4) which included medical institutions (5-7). This resulted in a high proportion of explosive injuries to civilians as well as soldiers (8).

Although Požega was not the target of a direct assault many civilians were injured (9). The town therefore offered a good model for the study of war-related injuries in civilians, not caused by direct combat activities. Our study focused on the circumstances of wound infliction, etiology of injuries, localization of injuries and results of treatment.

\section{Patients and Methods}

During the five years of war in Croatia (August 13, 1991 till January 1, 1996), 1,129 wounded were treated at the Požega County Hospital, $546(48.4 \%)$ of them as inpatients and $583(51.6 \%)$ as outpatients. Most $616(54.6 \%)$ were soldiers and policemen, and the remainder were civilians $131(11.6 \%), 11(1 \%)$ enemy soldiers and 371 (32\%) unknown. In the civilian group there were 86 men and 45 women, mean age 38.7 years (range 6-92 years). Most $(\mathrm{N}=108)$ were hospitalized, and only 23 were treated as outpatients. The mean duration of hospital treatment was 10.1 days (range $1-81$ days). There were $16(12.2 \%)$ children aged $<15$ years, one dying during the treatment.

\section{Results}

Most of the civilian injuries $55(42 \%)$ resulted directly from hostile action. Twenty-nine (22.1\%) resulted from accidents whilst handling weapons or explosive devices. In 25 (19\%) cases, mainly outpatients, the circumstances of wounding were unknown (Table 1).

\section{Table 1}

Circumstances of war wounding in 131 civilians treated at Požega Hospital during the 1991-1995 war period.

\begin{tabular}{|l|r|r|}
\hline Circumstances of wounding & N & $\%$ \\
\hline In action & 55 & 42.0 \\
Accident & 29 & 22.1 \\
Traffic & 1 & 0.8 \\
Fight and row & 12 & 9.2 \\
Suicide & 9 & 6.9 \\
Unknown & 25 & 19.0 \\
Total & 131 & 100.0 \\
\hline
\end{tabular}

Table 2

Aetiology of war injuries in civilians treated at Požegä Hospital during the 1991-1995 war period.

\begin{tabular}{|c|c|c|}
\hline Type of injury & $\mathbf{N}$ & $\%$ \\
\hline Gunshot & 51 & 38.9 \\
\hline Explosive & 75 & 57.3 \\
\hline Stroke, fall & 4 & 3.0 \\
\hline Unknown & 1 & 0.8 \\
\hline Total & 131 & 100.0 \\
\hline
\end{tabular}

With regard to aetiology, explosive wounds 75 (57.7 75 prevailed, followed by gunshot $51(38.9 \%)$ and othen wounds (Table 2).

The most common sites of injury were the extremities $(51.2 \%)$, head $29(22.1 \%)$ and abdominal region 18 (13.7\%). Monotrauma was found in $39(29.8 \%)$ f fle polytrauma in ten $(7.6 \%)$ civilians (Table 3 ).

Table 3

Localization of war injuries in civilians treated at Požega Hospital during the 1991-1995 war period.

\begin{tabular}{|l|r|r|}
\hline Localization & N & \multicolumn{1}{|c|}{$\%$} \\
\hline Head, face, neck & 29 & 22.1 \\
Thorax & 13 & 9.9 \\
Abdominal and lumbar region & 18 & 13.7 \\
Extremities & 67 & 51.2 \\
Unknown & 4 & 3.1 \\
Polytrauma & 10 & 7.6 \\
Monotrauma & 39 & 29.8 \\
Multiple wounds & 82 & 62.6 \\
\hline
\end{tabular}

In the management of 127 soft tissue injuries, primar suture was done in 35 patients, the majority $(\mathrm{N}=82)$ bein allowed to granulate (Table 4). Bone fractures were mostl? treated by plaster casts $(10)$ and external fixation. Af external fixator conversion by a flat Müller plate with autologous spongioplasty was performed in only on patient. There was a low proportion of penetrating wound to the thorax, abdomen, urogenital tract and head. The treatment of these is presented in Table 4.

Soft tissue infection was the most common complication $(9.9 \%)$, followed by nerve damage $(4.6 \%)$ and in five् (3.8\%) amputation of part of the extremities. (Four in 
Table 4

Treatment of war injuries in civilians at Požega Hospital.

\begin{tabular}{|l|l|r|r|}
\hline $\begin{array}{l}\text { Type of war } \\
\text { wound }\end{array}$ & Type of treatment & N & $\%$ \\
\hline Soft tissues & Primary suture & 35 & 27.6 \\
N=127 & Secondary suture & 5 & 3.9 \\
& Thiersch & 5 & 3.9 \\
& Granulation & 82 & 64.6 \\
Bone & Primary osteosynthesis & 1 & 3.3 \\
N=30 & Secondary osteosynthesis & 1 & 3.3 \\
& External fixator & 4 & 13.3 \\
& Cast & 10 & 33.3 \\
Penetrating & Segmentectomy & 2 & \\
Thoracic & Pulmonary suture & 1 & \\
N=5 & Cardiac suture & 2 & \\
Penetrating & Anus praeter & 2 & \\
Abdominal & Suture & 4 & \\
N=7 & Hemicolectomy & 1 & \\
Urogenital & Nephrectomy & 1 & \\
N=2 & Kidney suture & 1 & \\
Head & Craniotomy & 7 & \\
N=7 & Hemostasis & 7 & \\
\hline
\end{tabular}

Table 5

Complications of war injuries in civilians treated at Požega Hospital $(\mathrm{N}=131)$

\begin{tabular}{|l|r|c|}
\hline Complication & N & $\%$ \\
\hline Infection & 13 & 9.9 \\
Nerve damage & 6 & 4.6 \\
Blood arteries and heart & 3 & 2.3 \\
Amputation & 5 & 3.8 \\
fingers & 2 & \\
femur & 1 & \\
forearm & 2 & \\
Mortality & 7 & 5.3 \\
\hline
\end{tabular}

explosive injury and one in a gunshot wound). Seven $(5.3 \%)$ patients died, one of them a 6 -year-old child with cranial injury (Table 5).

\section{Case Reports}

Case I

A 23-year-old woman was admitted to the hospital, immediately after having attempted suicide by shooting herself in the left chest with a smallbore gun. She was in shocked and pale with a blood pressure of $80 / 40 \mathrm{~mm} \mathrm{Hg}$, pulse $100 / \mathrm{min}$, but conscious. A small, round entry wound was seen on her left chest, medial to the mamilla. The bullet was detected ultra sonographically and by radiology behind the left auricle. The wound localization indicated emergency left-sided thoracotomy. An abundance of liquid and clotted blood was found in the left thorax. Incision of the visible haemopericardium and removal of blood clots revealed a small wound to the right auricle which was bleeding. The wound was closed with finger pressure and
Table 6

War injuries in civilians according to total war traumatism in some Croatian towns.

\begin{tabular}{|l|c|rc|}
\hline Town (Ref. No.) & Total number & Civilians \\
of wounded & N & $(\%)$ \\
\hline Osijek (4) & 4,545 & 1,669 & $(36.7)$ \\
Sibenik (1) & 321 & 126 & $(39.3)$ \\
Dubrovnik (2) & 1,039 & 232 & $(22.3)$ \\
Vinkovci (9) & 1,186 & 437 & $(36.9)$ \\
Slavonski Brod (3) & 7,043 & 1,398 & $(19.8)$ \\
Virovitica (10) & 405 & 88 & $(21.7)$ \\
Požega (our data) & 1,129 & 131 & $(11.6)$ \\
\hline
\end{tabular}

stitched using a haemostatic suture. The bullet was found, and the pericardium was closed by continuous suture. A drain from the left thorax was connected to a negative pressure device. When hemostasis had been achieved a stratified thoracic wall suture was performed. The patient was then administered antibiotics, analgesics, sedatives, calorie and electrolyte infusions, and antitetanic prophylaxis.

The postoperative course was uncomplicated. Beside initial therapy, the patient received only one unit of blood. Diagnostic procedures were performed the following day. The cardiologist detected a short systolic murmur in the mesocardium, and slightly elevated ST segment at some ECG leads, which he explained by tachycardia $(130 / \mathrm{min})$. Laboratory findings were normal. The patient was transferred to the Rebro Department of Surgery, Zagreb University Hospital Center, 20 hours after the wounding.

\section{Case 2}

A 16-year-old boy was transported by an ambulance and admitted, after wounding to the left chest with a hunting gun. The patient was conscious but pale, sweating with a blood pressure of $90 / 60 \mathrm{~mm} \mathrm{Hg}$ and a pulse approximately $130 / \mathrm{min}$. Breath sounds were hardly perceptible over the left hemithorax. In the region of the left nipple, some 20 tiny wounds surrounded with subcutaneous emphysema were observed. An emergency exploratory operation was instigated. During skin cleansing the patient went into cardiac arrest. He was immediately resuscitated. and a leftsided posterolateral thoracotomy performed. A large amount of blood, found on opening the pleura, was removed. Incision of the very tight pericardium revealed two punctiform lesions to the right ventricle, while a third lesion had caused disruption of the left coronary artery, the latter was stitched by a "U" suture at which point the patient suffered a further arrest and further attempts at resuscitation were unsuccessful and the patient was declared dead 30 minutes after admission.

\section{Case 3}

A 26-year-old man suffered a gunshot wound to his right thigh, during enemy action in a village near Požega (Fig 1). He was transferred to the hospital within the hour. Intralesional soft tissue debridement, removal of 


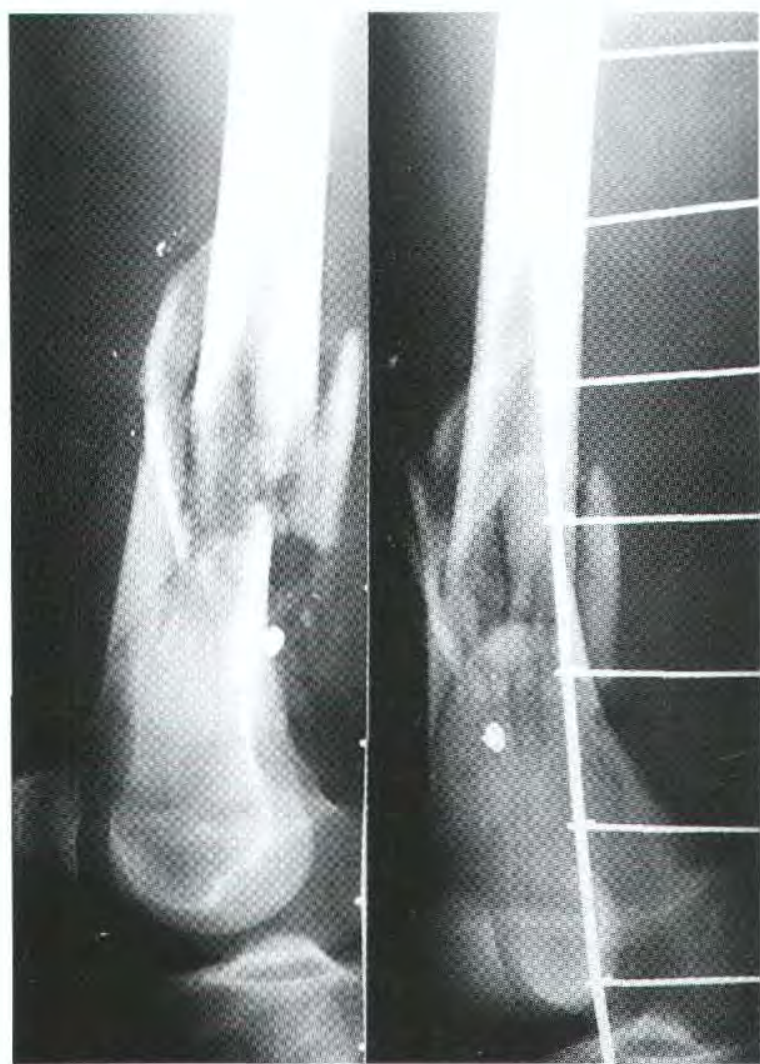

Fig. 1. Multifragmental supracondylar fracture of the right femur

accessible foreign bodies and devitalized bone fragments, fascial incision for oedema, and haemostasis were performed under a general, endotracheal anaesthesia. The wound was not sutured and the fracture was stabilized with an external fixator (Fig 2). The wound healed in three weeks but because of the patient's poor self discipline secondary osteosynthesis (conversion) with a condylar angular plate was required four weeks after wounding. The patient was from Bosnia and he chose to return there to join the army. He presented for control examination 12 months after the wounding (Fig 3), when the graft was removed. The functional result was excellent.

\section{Discussion}

During the war in Croatia, the town of Požega was not directly attacked, but its surroundings were the scene of major war actions on three occasions (8), posing specific demands upon the Požega Hospital Department of Surgery.

The periods of action on the Požega front were from July 16, 1991 to April 22, 1992 with 582 wounded, in the neighbouring Bosanka Posavina April 23, 1992 to December 30, 1992 with 388 wounded, and the "peaceful" period 1993- 1995 with 159 war wounds. In addition the town of Požega was exposed to several air-raids in 1991,

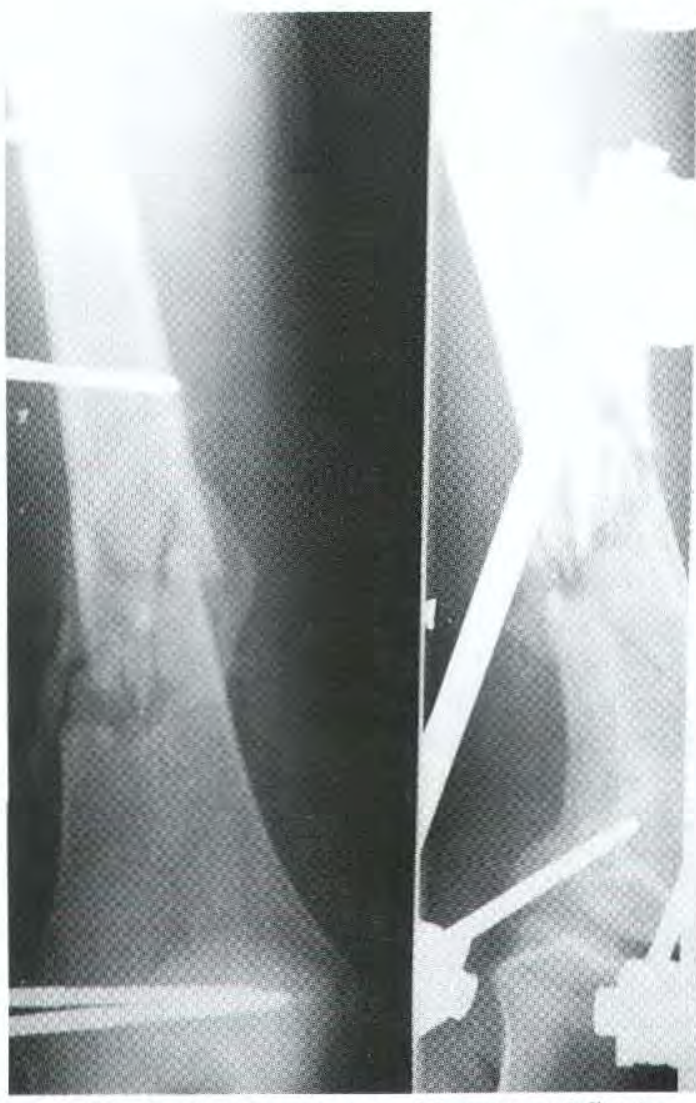

Fig. 2. Fixatio externa with external fixator.

and shelling with cluster bomb in 1995.
Analysis of the wounded civilians (Tables 1-3) indicate three main features, i.e.. aetiology (explosions), sites of injury (extremities and head) and circumstances o wounding (on the front), because residential areas at the frontline (villages in the Požega surroundings and towns it Bosanska Posavina) were the scene of war actions. These characteristics were also recorded as well as in othe related analyses (1-4). Weapons had previously beet⿱⺻灬 unavailable to the Croats, until the onset of the war. This could account for the increased use of arms in variou stress situations ( $7 \%$ of suicides, Table 1 ).

In Požega, the proportion of wounded civilians was noţ very high, because the town was not directly attacked $(8)$ unlike other towns $(1,4,9,10)$, where the civilian traum $\delta$ ranged from $20 \%$ to $40 \%$ (Table 6 ). All these towns were attacked by heavy artillery, from air, water and groundo which not surprisingly resulted in higher total number o casualties than in Požega (Table 6).

Although we followed the principles of war surger (11), our shortcomings were evident, for example there were two secondary procedures involving the use of Thiersch's plastics, where there was an excess ow granulation tissue. The study also revealed inappropriate keeping of medical records (19\% of unrecorded case 


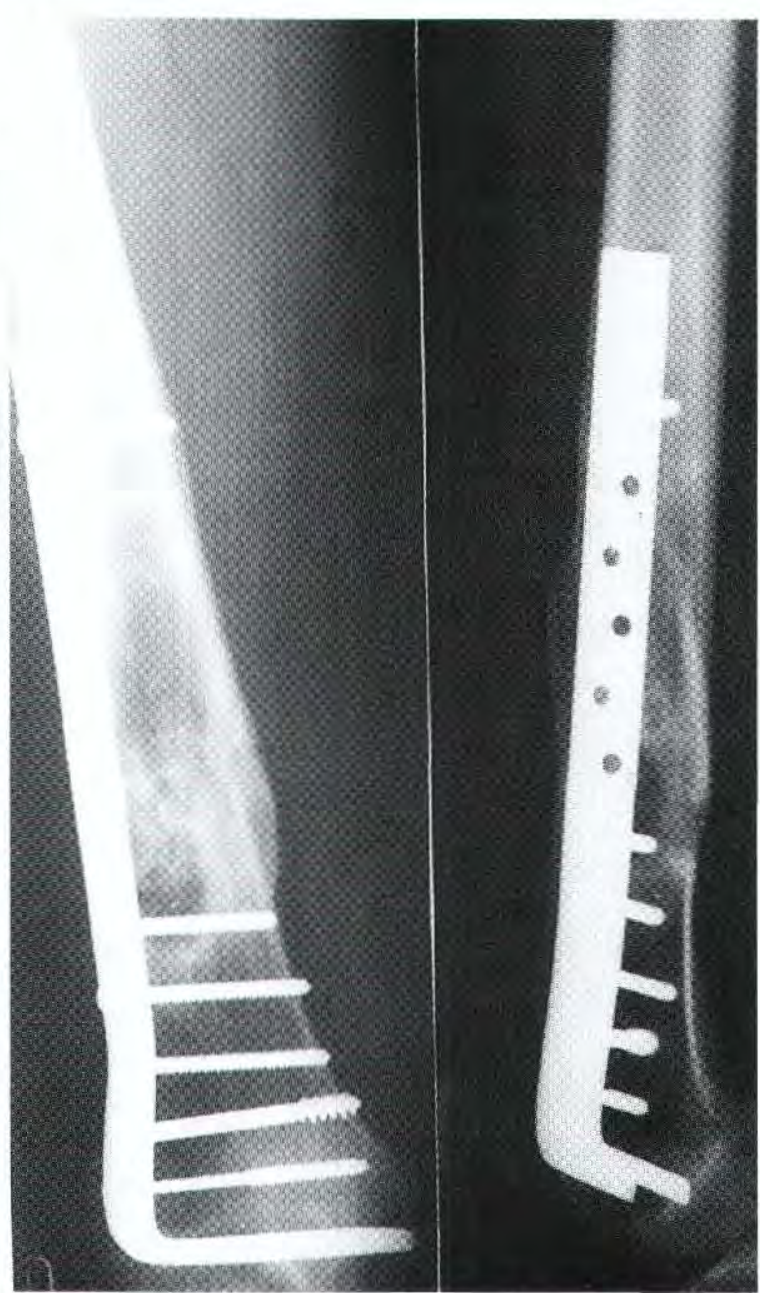

Fig. 3. The fracture from Figures 1 and 2, twelve months after spongioplasty and secondary osteosynthesis with condylar angular plate.

Table 1), which could by no means be justified by the delay in computerization (1993). There were no generalized infections (tetanus, gas gangrene, sepsis, osteitis), although local infections $(9.9 \%)$ exceed the percentages reported elsewhere (4). Five penetrating thoracic injuries were all treated with thoracotomy (Table 4) asking the question as to whether all these procedures were really necessary.
The mortality rate was high $(5.3 \%)$ compared to total mortality of the Požega military $28(2.5 \%)$ and the figures of some other Croatian towns (1-4).

\section{Acknowledgement}

I thank Drs Ana and Matko Marušić for encouragement and help with preparation of the manuscript.

\section{REFERENCES}

1. Batinica J, Batinica S. War wounds in the Sibenik area during the 1991-1992 war against Croatia. Milit Med, 1995; 160: 124-8.

2. Bogdanović S, Margaritoni M JR, Kotić N, et al. Dubrovnik General Hospital: civilian surgery in the besieged town. Croatian Med J 1994; 35: 94-9.

3. Balen I, Prgomet D. Danić D, Puntarić D. Work of the Slavonski Brod General Hospital during the war in Croatia and Bosnia and Herzegovina in 1991-1992. Milit Med 1995; 160: 588-92.

4. JANOŠI K, LOVRIĆ Z. War surgery in Osijek during 1991/92 war in Croatia. Croatian Med J 1995; 36: 104-7.

5. Kostović I, Marušıć M. Attacks of Croatia's hospitals. Lancet 1991; 338: 26.

6. MaRKelJeVIĆ J, LACKOVIĆ $\mathrm{Z}$. The case of Croatian? hospitals: is this the end of humanitarian rules? $\mathrm{Med} \stackrel{\mathrm{\Phi}}{\mathrm{D}} \mathrm{O}$ War 1994; 10: 50-62.

7. Marcikić M, Kraus Z, Dmitrović B, Mošunjac M, $\stackrel{\mathbb{Q}}{\complement}$ MARUŠÍ A. Heavy artillery attack on the Pulmonary Ward of the Osijek General Hospital. Croatian Med 18 1992; 33 (War Suppl 2): 70-4.

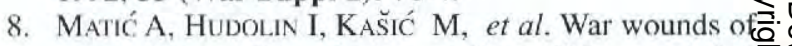
extremities. Experience with 480 wounded? extremities. Med Vjesn 1993; 25: 157-62.

9. Rukavina A, Glavić Ž Fajdić J, Vukoja M, Gveric D, Mustapić S. War-related transformation and work of Surgery Service of the Požega Medical Center, an east-Croatian hospital unaffected by direct war activities. Milit Med 1995; 160: 604-8.

10. Katanušić J, Feketec S, Moslovac S. Fett M. Medicinski centar Virovitica u specifičnim uvjetima godine 1991/92. Med Vjesn 1992; 24: 127-30.

11. Bowen TE, Bellamy RF, eds. Emergency war surgery. Second United States Revision of the Emergency War Surgery NATO Handbook. Washington, DC: United States Department of Defense, United States Government Printing Office, 1988.m 